\title{
Impacts of high-nitrate freshwater inputs on macrotidal ecosystems. I. Seasonal evolution of nutrient limitation for the diatom-dominated phytoplankton of the Bay of Brest (France)
}

\author{
Yolanda Del Amo ${ }^{1, *}$, Olivier Le Pape ${ }^{2}$, Paul Tréguer $^{1}$, Bernard Quéguiner $^{1}$, \\ Alain Ménesguen ${ }^{2}$, Alain Aminot ${ }^{2}$ \\ 'UMR CNRS 6539 'Bioflux', Université de Bretagne Occidentale, Institut Universitaire Européen de la Mer, \\ Technopole Brest-Iroise, Place Nicolas Copernic, F-29280 Plouzané, France \\ ${ }^{2}$ Laboratoire 'Chimie et Modélisation des Cycles Naturels', Direction de l'Environnement Littoral, IFREMER, BP 70 ,
} F-29280 Plouzané, France

\begin{abstract}
The chemical factors (inorganic nitrogen, phosphate, silicic acid) that potentially or actually control primary production were determined for the Bay of Brest, France, a macrotidal ecosystem submitted to high-nitrate-loaded freshwater inputs (winter nitrate freshwater concentrations $>700 \mu \mathrm{M}$, Si:N molar ratio as low as 0.2 , i.e. among the lowest ever published). Intensive data collection and observations were carried out from February 1993 to March 1994 to determine the variations of physical [salinily, temperature, photosynthetically active radiation (PAR), freshwater discharges] and chemical (oxygen and nutrients) parameters and their impacts on the phytoplankton cycle (fluorescence, pigments, prmary production). With insufficient PAR the winter stocks of nutrients were almost nonutilized and the nitrate excess was exported to the adjacent ocean, due to rapid tidal exchange. By early April, a diatom-dominated spring bloom developed (chlorophyll a maximum $=7.7 \mu \mathrm{g} \mathrm{l}^{-1}$; primary production maximum $=2.34 \mathrm{~g} \mathrm{C} \mathrm{m}^{-2} \mathrm{~d}^{-1}$ ) under high initial nutrient concentrations. Silicic acid was rapidly exhausted over the whole water column; it is inferred to be the primary limiting factor responsible for the collapse of the spring bloom by mid-May. Successive phytoplankton developments characterized the period of secondary blooms during summer and fall (successive surface chlorophyll a maxima $=3.5$, 1.6, 1.8 and $1.0 \mu \mathrm{g} \mathrm{I}^{-1}$; primary production $=1.24,1.18$ and $0.35 \mathrm{~g} \mathrm{C} \mathrm{m}^{-2} \mathrm{~d}^{-1}$ ). Those secondary blooms developed under lower nutrient concentrations, mostly originating from nutrient recycling. Until August, Si and $\mathrm{P}$ most likely limited primary production, whereas the last stage of the productive period in September seemed to be $N$ limited instead, this being a period of total nitrate depletion in almost the whole water column. Si limitation of spring blooms has become a common feature in coastal ecosystems that receive freshwater inputs with Si:N molar ratios $<1$ The peculiarity of Si limitation in the Bay of Brest is its extension through the summer period.
\end{abstract}

KEY WORDS: Coastal ecosystem - Phytoplankton dynamıcs Macrotıdal - Nutrient limitation Sulicon Eutrophication

\section{INTRODUCTION}

The long-term increase of anthropogenic inputs of nitrogen and phosphorus into the coastal waters of most developed countries (Howarth et al. 1996) has 3

\footnotetext{
- Present address: Department of Ecology, Evolution and Marine Biology, Marine Science Institute, University of California, Santa Barbara, Californı 93106, USA.

E-mail: delamo@lifesci.lscf.ucsb.edu
}

potential consequences. First, it can induce a spectacular enhancement of the productivity of phytoplankton populations that were previously $N$ and/or $P$ limited, leading to severe eutrophication problems (Meybeck \& Helmer 1989, Smayda 1990). Second, declines in dissolved Si:N ratios in coastal waters can induce subsequent silicic acid ( $=$ 'silicates') limitation of diatomdominated populations (Officer \& Ryther 1980, Smayda 1990, Conley \& Malone 1992, Conley et al. 1993). Third, this Si limitation can disturb the typical suces- 
sion of phytoplankton in temperate waters and provoke a shift of dominance from siliceous (diatoms) to non-siliceous (flagellates) species (Billen et al. 1991).

Numerous studies have already focused on the eutrophication of ecosystems highly loaded with $\mathrm{N}$ and $\mathrm{P}$ (review in Howarth et al. 1996) but the importance of Si as a limiting factor of phytoplankton growth has long been ignored (e.g. Tréguer et al. 1995) and only a few studies (Smayda 1990, Egge \& Aksnes 1992, Bodeanu 1993) have envisaged the impact of the decline of the Si:N ratios in coastal waters on the composition of phytoplankton populations. The aim of this paper is to address the question of how the chemical factors (nitrogen, phosphorus, silicon) potentially or actually control pelagic primary production during the different seasons of a complete annual cycle in a macrotidal ecosystem of western Europe (the Bay of Brest, France), which receives freshwaters that have been dramatically enriched in nitrate in recent decades (Del Amo 1996, Le Pape et al. 1996). The response of the phytoplankton community structure to this nitrate perturbation is presented in a companion paper (Del Amo et al. 1997).

Among world ocean coastal waters, those of western Europe are characterized by an intensive tidal exchange with the ocean. The Bay of Brest is a typical macrotidal ecosystem that is strongly influenced by freshwater inputs originating from 2 main rivers: Elorn River, discharging in the northern basin, and Aulne River, in the south, whose catchment areas are submitted to intensive agriculture runoff (Daniel 1995). This semi-enclosed basin of $180 \mathrm{~km}^{2}$ is connected to the Atlantic Ocean (Iroise Sea) by the Brest Channel, which is $1.8 \mathrm{~km}$ wide and $50 \mathrm{~m}$ deep. Except for the fairways of the main rivers and the Brest Channel, the Bay is generally shallow: more than $50 \%$ of the total area is $<5 \mathrm{~m}$ deep, and only $13 \%$ is more than $20 \mathrm{~m}$ deep. Between $1 / 35$ and 1/25 of the Bay volume is renewed at each tide (maximum tidal amplitude: $8 \mathrm{~m}$; tide periodicity: 12 h 15 min) by the ocean (Delmas \& Tréguer 1983). Strong tidal currents (maximum tidal currents: $2.6 \mathrm{~m} \mathrm{~s}^{-1}$; SHOM 1968) coupled with surface wind stress induce rapid vertical mixing of the Bay water, hindering the typical summer stratification observed in other coastal ecosystems (D'Elia et al. 1992, Turner \& Rabalais 1994, Malej et al. 1995).

Within the framework of a multidisciplinary study (Contrat de Baie), an intensive data collection was carried out in the Bay of Brest during the 1993-1994 annual cycle, to describe the seasonal pattern of phytoplankton primary production and community structure in relation to nutrient availability and the physical environment. Although during the last 20 yr the riverine discharge of nitrate into the Bay has doubled, neither did the annual amount of phytoplankton biomass increase nor the oxygen concentrations above the sediments significantly decrease (Le Pape et al. 1996). The resistance of this ecosystem to eutrophication has been explained by the fast renewal rate of the Bay water (Delmas 1981). Although non-eutrophicated, the Bay is definitely chemically perturbed, as evidenced by the long-term decrease of the Si:N ratio (silicic acid : nitrate + nitrite + ammonium) during summer from 2.00 in 1975 to 0.33 in 1993 (Del Amo 1996, Le Pape et al. 1996). Consequences of such a drastic change in the chemical composition of the Bay of Brest waters on the spring phytoplankton dynamics have been partly described by Ragueneau et al. (1994), who suggested that the 1992 diatom-dominated bloom collapsed due to Si limitation. Because the dominance of diatoms was known to occur not only during spring but during the entire productive period (Quéguiner \& Tréguer 1984), this study is concerned with the investigation of the chemical control of phytoplankton during the complete annual cycle of 1993-1994.

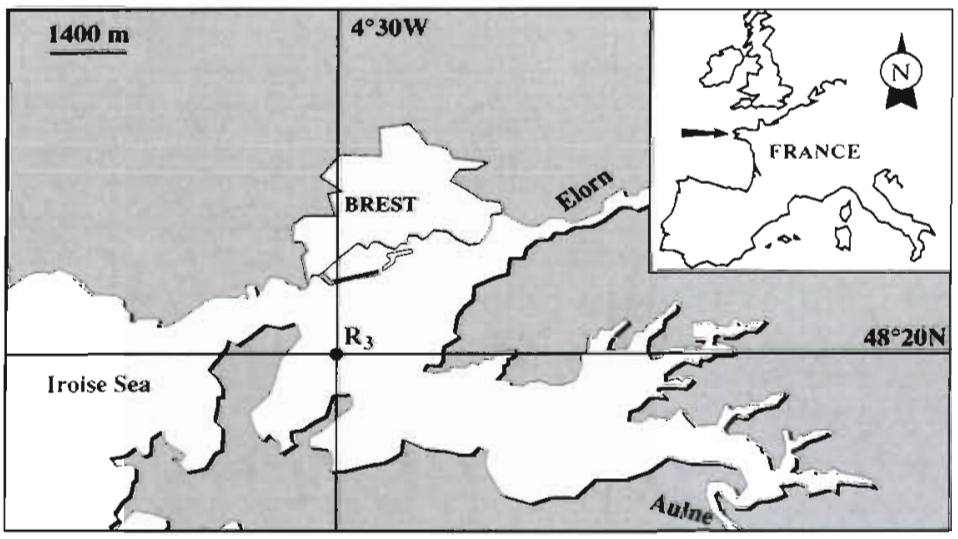

Fig. 1. Study area and location of station $\left(R_{3}\right)$ sampled during 1993-1994 in the Bay of Brest, France

\section{MATERIALS AND METHODS}

Sampling strategy. Thirty cruises were conducted in the Bay of Brest (Fig. 1) from 15 February 1993 to 21 March 1994; sampling frequency ranged from twice a week during spring to once a month during winter. As phytoplankton developments have already been shown to respond to decreasing tidal mixing (Ragueneau et al. 1996), sampling dates were chosen close to neap tides. Water sampling was performed at $\operatorname{Stn} \mathrm{R}_{3}\left(48^{\circ} 20^{\prime} \mathrm{N}\right.$, $4^{\circ} 30^{\prime} \mathrm{W}$ ), located in the mixing area between waters of the northern and southern basins of the Bay of Brest and the ocean (Delmas 1981, Quéguiner 1982, Delmas \& Tré- 
guer 1983). Stn $R_{3}$ is considered as typical of the major part of the Bay (see Ragueneau et al. 1994 for details), and has been extensively studied during the last $20 \mathrm{yr}$ [R.N.O. (Réseau National d'Observation de la qualité du miliue marin, Ministèrie de l'Environnement, Francel database, Quéguiner \& Tréguer 1984, Jacq et al. 1985, Dauchez et al. 1991, Ragueneau et al. 1994, 1996, Daniel 1995].

Salinity, temperature, fluorescence and photosynthetically active radiation (PAR) profiles were made by using a Seabird SBE 19 Seacat CTD profiler, coupled with a LiCor LI-1000 PAR sensor. Discrete sampling was carried out by using $8 \mathrm{l}$ or $30 \mathrm{l}$ Niskin samplers, fitted with non-toxic silicone tubings, at depths corresponding respectively to 100 (surface), 25, 10, and $1 \%$ of surface PAR, and $2 \mathrm{~m}$ above the bottom.

Ammonium and dissolved oxygen samples were immediately fixed by addition of the working reagents Nutrient samples were either stored at $4^{\circ} \mathrm{C}$ for silicic acid analysis, or frozen $\left(-20^{\circ} \mathrm{C}\right)$ for nitrate + nitrite and phosphate measurements. Filtrations for particulate organic carbon (POC) and nitrogen (PON), as well as for pigments [chlorophyll a (chl a) and phaeopigments], were also done immediately after sample collection. Dissolved oxygen, nutrients and carbon uptake measurements were performed at the 5 sampled depths, whereas measurements of pigments, POC, and PON were restricted to surface samples.

Daily river flow data for Elorn and Aulne Rivers were provided by Direction Régionale de l'Environnement Service du bassin Loire Bretagne. Solar radiation data were provided by Météorologie Nationale (BrestGuipavas weather station).

Analytical methods. Salinity values measured by the CTD were calibrated against discrete surface and bottom measurements which were made using a Guildline Autosal 8400 salinometer, precision: \pm 0.001 psu. Dissolved oxygen was analyzed by the Winkler method according to Strickland \& Parsons (1972), precision: $\pm 0.6 \%$. Ammonium was analyzed according to Koroleff (1969), precision: $\pm 3 \%$. Nitrate + nitrite and silicic acid concentrations were determined according to the spectrophotometric method of Gordon et al. (1993) using an Alpkem RFA-300 Analyzer, precision: $\pm 0.8 \%$ for nitrate + nitrite and $\pm 0.5 \%$ for silicic acid. Phosphate concentrations were measured on a Technicon Auto Analyzer II, according to Tréguer \& Le Corre (1975), precision: $\pm 1 \%$.

For chl a and phaeopigment determinations, 0.5 to 1.01 seawater was filtered through $0.6 \mu \mathrm{m}$ Nuclepore filters, which were immediately frozen $\left(-20^{\circ} \mathrm{C}\right)$ until further analysis by the fluorometric method of Yentsch \& Menzel (1963), using a calibrated Turner 112 fluorometer, precision: $\pm 1 \%$. For POC and PON measurements, 0.5 to 1.0 l seawater was filtered through precombusted $\left(450^{\circ} \mathrm{C}\right.$ for 4 h.) Whatman GF/F filters, which were immediately frozen $\left(-20^{\circ} \mathrm{C}\right)$ until further analysis on a modified Carlo Erba analyzer model $\mathrm{N}$ 1500 , following the method of Strickland \& Parsons (1972), precision: $\pm 1 \%$.

For primary production measurements 24 h dawn-todawn incubations were performed under simulated in situ conditions by using nickel screens of various light transmissions. $1 \mathrm{ml}$ (ca $147 \mathrm{kBq}$ ) of $\mathrm{NaH}^{14} \mathrm{CO}_{3}$ solution (Carbon 14 Centralen $($, Denmark) was added to $250 \mathrm{ml}$ of unprefiltered seawater into polycarbonate bottles. After incubation, samples were filtered onto $0.6 \mu \mathrm{m}$ Nuclepore filters, which were kept frozen until processing. At the laboratory, filters were dried at $30^{\circ} \mathrm{C}$ for $12 \mathrm{~h}$ and counted by liquid scintillation on a Packard Tri-Carb model 1600 TR liquid scintillation counter without previous acidification. Total $\mathrm{CO}_{2}$ was estimated to be $2200 \mu \mathrm{M}$ for calculation of incorporated ${ }^{14} \mathrm{C}$. Specific activities of each serial batch of the ${ }^{14} \mathrm{C}$ stock solutions were given by the supplier and were double-checked at the laboratory by drawing $20 \mu \mathrm{l}$ of the radioactive solution into a scintillation vial containing $50 \mu \mathrm{l} 6 \mathrm{~N} \mathrm{NaOH}$, followed by addition of liquid scintillation cocktail, which was then immediately measured (to avoid any $\mathrm{CO}_{2}$ loss) by liquid scintillation. No attempt was made to measure dark or timezero uptake of ${ }^{14} \mathrm{C}$. Water column integrated primary production ( $m$ mol $\mathrm{C} \mathrm{m}^{-2} \mathrm{~d}^{-1}$ ) was calculated by trapezoidal integration of the individual depth profiles of daily primary production. The rate nearest to the surface ( $1 \mathrm{~m}$ depth) was assumed to be constant up to $0 \mathrm{~m}$, and the one nearest to the bottom $(2 \mathrm{~m}$ above sediment) was assumed to be constant down to the bottom.

\section{RESULTS}

\section{The physical environment}

The highest river flows recorded during the study period mainly occurred during winter (Fig 2a); these events followed the usual seasonal pattern, although they were much more pronounced in comparison with the 1970-1992 average evolution. Some smaller water discharges occurred during spring, while summer was characterized by very low river flows. Daily solar radiation (Fig. 2b) followed the seasonal evolution of temperate areas. The lowest values were observed in winter $\left(<500 \mathrm{~J} \mathrm{~cm}^{-2} \mathrm{~d}^{-1}\right)$, while summer maximum values reached $3500 \mathrm{~J} \mathrm{~cm}^{-2} \mathrm{~d}^{-1}$. However, the solar radiation was characterized by a high day-to-day variability, and values as low as $700 \mathrm{~J} \mathrm{~cm}^{-2} \mathrm{~d}^{-1}$ (i.e. close to winter maxima) were frequently measured during summer. Surface PAR ranged from 40 (December 1994) to $1700 \mu \mathrm{E} \mathrm{m}^{-2} \mathrm{~s}^{-1}$ (May 1993) and the photic depth (1\% of surface PAR) ranged from $15 \mathrm{~m}$ (February 1994) to 

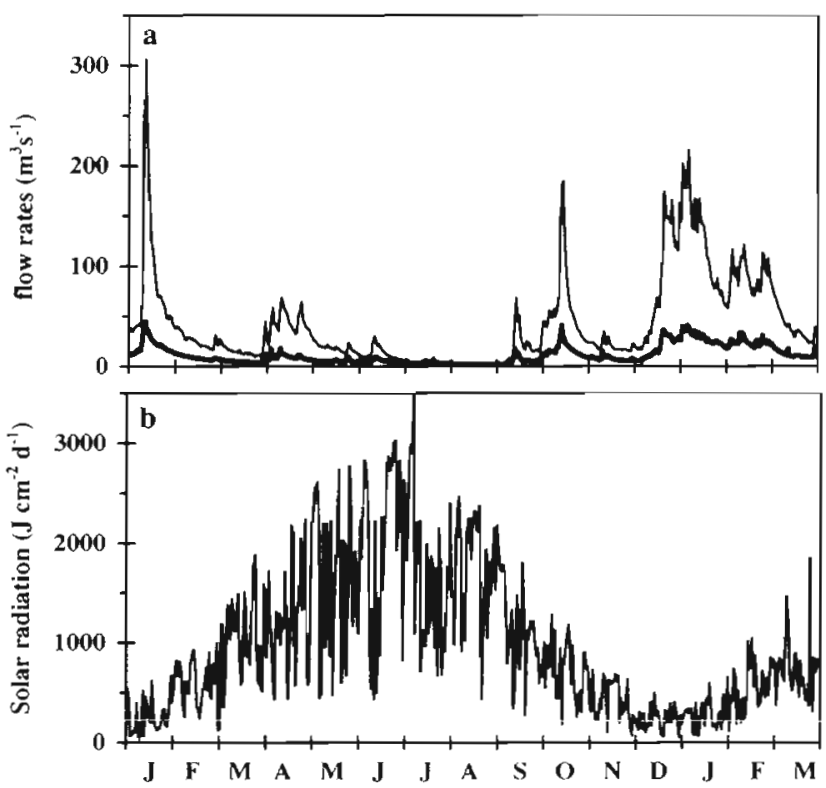

Fig. 2. Time-course variations of meteorological parameters. (a) Averaged daily flow rates of Aulne (thin line) and Elorn (thick line) Rivers; (b) daily integrated solar radiation

$33 \mathrm{~m}$ (August 1993), equivalent to an extinction coefficient $k$ ranging from 0.29 to $0.15 \mathrm{~m}^{-1}$

Water temperatures at Stn $\mathrm{R}_{3}$ (Fig. 3a) were characterized by a late winter minimum $\left(<8.0^{\circ} \mathrm{C}\right.$ in surface waters in January-February 1994) and a summer maximum $\left(16.9^{\circ} \mathrm{C}\right.$ by mid-August 1993). The vertical structure of temperature was homogeneous all year round, except during the winter minimum when a weak thermal gradient developed under the conjunction of solar radiation minima (Fig. 2 b) and heavy freshwater inputs (Fig. 2a). As evidenced by the low salinity variations (generally $>33.00$ psu; Fig. 3b), the Bay of Brest behaves all year round like a typical marine ecosystem, due to the importance of tidal exchange with the ocean. Salinity was homogeneously distributed with depth, except during high river discharge events (January-February 1994) that caused a decrease in surface water salinity down to 30.53 psu. Due to the vertical homogeneity of temperature, water density $\left(\sigma_{t}\right)$ was mainly affected by salinity variations (Spearman's $r_{s}$ of 0.60 ; Table 1), and 3 periods of weak stratification were observed during the study period (Fig. 3c): in early April 1993, as well as in fall and winter.

\section{The chemical environment}

High nitrate concentrations (Fig. 4a) characterized the surface waters during winter. A transitory maximum surface concentration $(83.4 \mu \mathrm{M})$ was reached in January 1994 just after heavy rainfalls. However, during February and March 1993 weaker freshwater inputs allied to phytoplankton uptake as well as to continuous water tidal exchange with the ocean were responsible for a gradual decrease of the surface nitrate from 49.4 to $10.1 \mu \mathrm{M}$. Indeed, this latter value was close to the nitrate concentration of the ocean surface water at the same period $(9.4 \mu \mathrm{M}$ ) at the Iroise Sea station (Del Amo 1996). In April 1993, occasional freshwater inputs introduced new nutrients and gave rise to high surface nitrate concentrations $(39.3 \mu \mathrm{M})$ during the onset of the spring bloom. The influence of river inflows on nutrients of the Bay waters is evidenced by the correlation coefficients between freshwater discharges (and salinity) and nutrients concentrations (nitrate and silicic acid; Table 1). During the course of spring and summer, phytoplankton population growth was accompanied by the decrease of nitrate; undetectable concentrations (i.e. $<0.05 \mu \mathrm{M}$ ) were observed in almost the whole water column in early September (Fig. 4a). Ammonium concentrations were also low $i<0.8 \mu \mathrm{M}$ throughout the water column) from early April to early September, as shown in Fig. 4b. Ammonium concentrations, which reflect the balance between loss (phytoplankton uptake and marine water renewal) and regeneration

Table 1. Rank correlation matrix (Spearman's $r_{s}$ ) of main physical and chemıcal parameters of the Bay of Brest for the $1993-1994$ annual cycle. $n=27 ; \cdots p<0.001, \cdots p<0.01, " p<0.05$

\begin{tabular}{|c|c|c|c|c|c|c|c|c|c|c|}
\hline & $\begin{array}{c}\text { Aulne } \\
\text { discharge }\end{array}$ & $\begin{array}{c}\text { Elorn } \\
\text { discharge }\end{array}$ & $\begin{array}{l}\text { Global } \\
\text { radiation }\end{array}$ & $\begin{array}{c}\text { Tempera- } \\
\text { ture }\end{array}$ & Salinity & $\sigma_{1}$ & Nitrate & $\begin{array}{l}\text { Silicic } \\
\text { acid }\end{array}$ & $\begin{array}{l}\text { Ammon- } \\
\text { ium }\end{array}$ & $\begin{array}{l}\text { Phos- } \\
\text { phate }\end{array}$ \\
\hline Aulne discharge & & $0.89^{\cdots}$ & -0.27 & $-0.51 \cdots$ & $-0.77 \cdots$ & $-0.39^{\circ}$ & $0.62 \cdots$ & 0.27 & 0.19 & 0.2 .5 \\
\hline Elorn discharge & & & $-0.42^{*}$ & $-0.50^{\circ}$ & $-0.69 \cdots$ & -0.31 & $0.57^{\cdots}$ & $0.39^{\circ}$ & 0.33 & 0.38 \\
\hline Global radiation & & & & $0.53 \cdots$ & 0.28 & -0.18 & $-0.45^{\circ}$ & $-0.49^{\circ}$ & $-0.46^{\circ}$ & $-0.67^{\cdots} \cdots$ \\
\hline Temperature & & & & & $0.70^{\cdots}$ & -0.07 & $-0.76 \cdots$ & -0.35 & -0.31 & $-0.46^{\circ}$ \\
\hline Salinity & & & & & & $0.60^{\cdots}$ & $-0.81 \cdots$ & -0.31 & -0.11 & -0.26 \\
\hline$\sigma_{1}$ & & & & & & -0.32 & -0.11 & 0.18 & 0.05 & \\
\hline Nitrate & & & & & & & & $0.62 \cdots$ & 0.35 & $0.61^{\cdots}$ \\
\hline Silicic acid & & & & & & & & & $0.76^{\cdots}$ & $0.92 \cdots$ \\
\hline Ammonium & & & & & & & & & & $0.80^{\cdots}$ \\
\hline
\end{tabular}



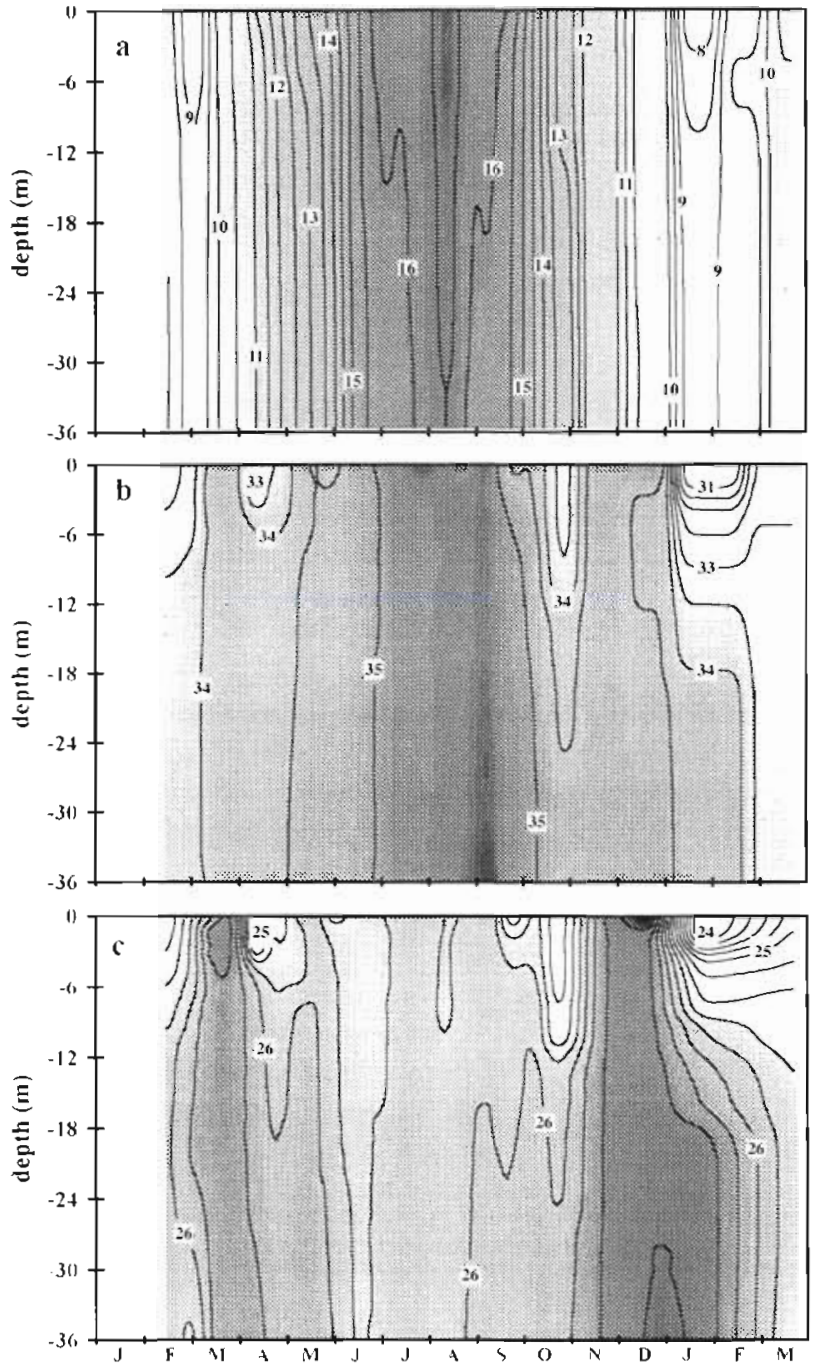

Fig 3 Seasonal variations of physical parameters at $\operatorname{Stn} R_{3}$ (Bay of Brest) durng 1993-1994 based on CTD profıler measurements. (a) Temperature in ${ }^{\circ} \mathrm{C}$, (b) salmity in psu, (c) density $\left(\sigma_{1}\right)$

processes (grazer excretion and bacterial remineralization), remained low $(\leq 1 \mu \mathrm{M})$ during most of the year The end of the phytoplankton uptake period in October was marked by a transitory ammonium increase (up to $22 \mu \mathrm{M})$, afterwards, concentrations stabilized around $1 \mu \mathrm{M}$ during winter The seasonal variations of silicic acld and phosphate (Fig $4 c, d$ ) were close to that of nitrate $\left(r_{s}=0.62\right.$ and 0.61 for silicic ac1d and phosphate, respectively, Table 1), with high winter concentrations during periods of freshwater inputs and low summer concentrations reflecting a net phytoplankton uptake. The most prominent feature in the silicic acid evolution (Fig 4c) was the decrease to undetectable concentrations over the whole water column from 27 April to 3 May following uptake by diatoms. After the spring bloom, the enhancement of biogenic silica dissolution
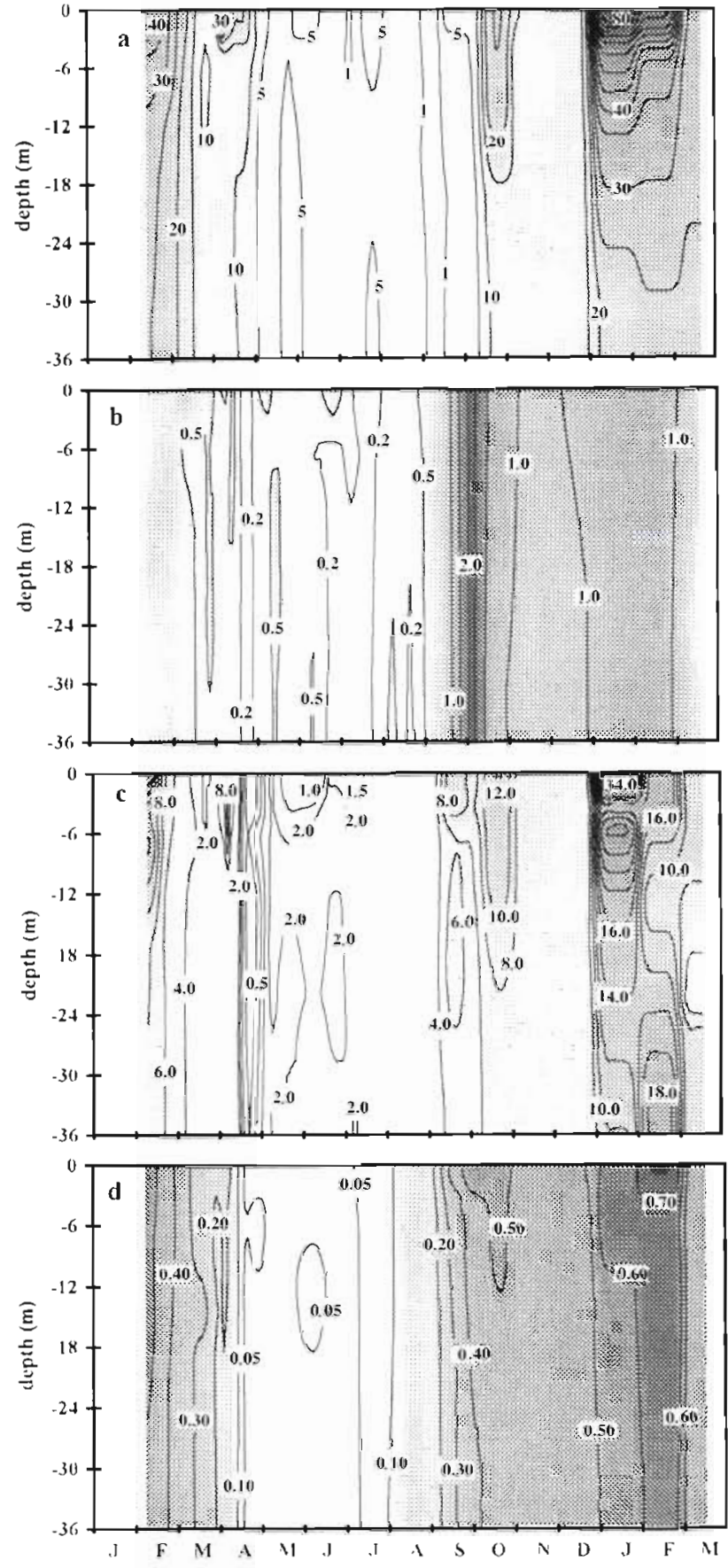

Fig 4 Seasonal variations of nutrient concentrations (in $\mu \mathrm{M}$ ) at Stn R durng 1993-1994 (a) Nitrate+nitrite, (b) ammonıum, (c) silicic acid, (d) phosphate

in bottom waters (Ragueneau et al. 1994) caused the gradual increase of silicic acid concentrations (with faster increase in bottom waters; Fig. 4c). Concentrations remained below $4 \mu \mathrm{M}$ throughout the water column untll the resumption of freshwater inputs in September Phosphate (Fig. $4 \mathrm{~d}$ ) remained $<0.8 \mu \mathrm{M}$ all year round. The lowest concentrations $(<0.1 \mu \mathrm{M})$ were ob- 

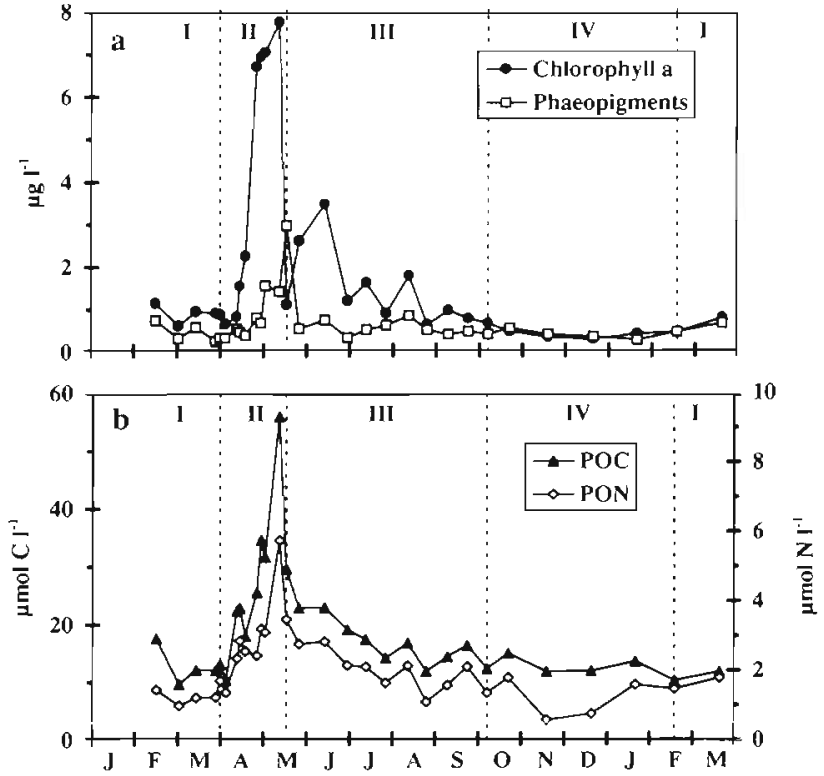

Fig. 5. Time-course variations of biomass in surface waters at Stn $R_{3}$ during 1993-1994. (a) Chlorophyll a and phaeopigments; (b) particulate organic carbon and nitrogeñ. Verticá dashed lines delimit the different periods distinguished during the annual plankton cycle: I, spring transition; II, spring bloom; III, secondary blooms; IV, fall/winter (see text for details)

served from late April to early August, reaching undetectable values (i.e. $<0.02 \mu \mathrm{M}$ ) only on 1 occasion in surface waters (18 May).

\section{The biological cycle}

Based on the seasonal patterns of biomass parameters (Fig. 5) and primary production (Fig. 6), we divided the annual cycle into 4 periods characterized by distinct features: Phase $I$, the spring transition period (15 February to 1 April 1993), shows slight increases in biomass and primary production; Phase II, the spring bloom period (1 April to 1.8 May 1993), is marked by the rapid increase of the phytoplankton biomass and primary production; Phase III, successive phytoplankton developments of smaller amplitude characterize the secondary blooms period (18 May to 7 October 1993), and Phase IV, the fall/winter period ( 7 October 1993 to 17 February 1994), is the period of lowest phytoplankton biomass and activity.

\section{Biomass parameters}

Surface chl a concentrations (Fig 5a) remained under $1 \mu \mathrm{g} \mathrm{l}^{-1}$ until 15 April. During the spring bloom, surface chl a reached its annual maximum $\left(7.7 \mathrm{Mg} \mathrm{l}^{-1}\right.$

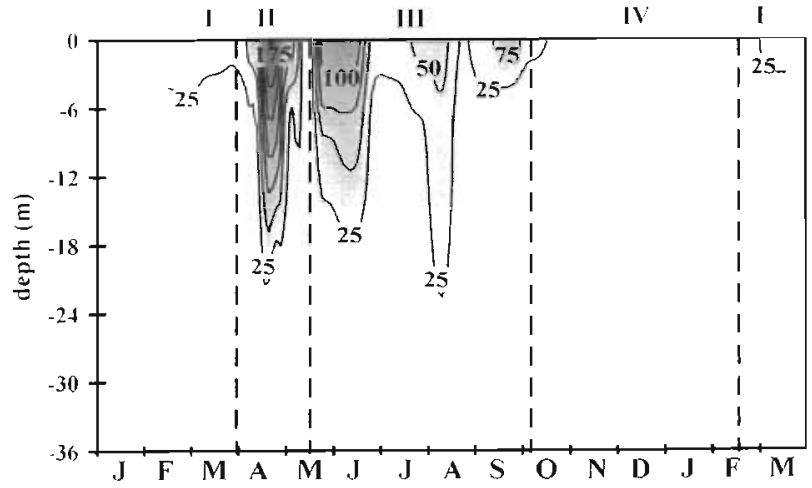

Fig. 6. Seasonal evolution of primary production rates (in mg $\mathrm{C} \mathrm{m}^{-3} \mathrm{~d}^{-1}$ ) at Stn $\mathrm{R}_{3}$ during 1993-1994. Vertical dashed lines and numbers as in Fig. 5

on 13 May). The secondary blooms period was then characterized hy surcessive peaks showing a somewhat gradual decreasing trend until the end of the period. Except during the secondary blooms period, the evolution of phaeopigments (Fig. 5a) was generally close to that of chl $a$, with a distinct maximum at the end of the spring bloom (3.0 $\mu \mathrm{g} \mathrm{I}^{-1}$ on 18 May).

The same observation was also made for POC and PON (Fig. 5b): only maximum concentrations $(55.8 \mu \mathrm{mol}$ $\mathrm{Cl}^{-1}$ and $5.8 \mu \mathrm{mol} \mathrm{N} \mathrm{l}^{-1}$ ) were simultaneous with the chl a maximum of 13 May. Concentrations then decreased gradually during the secondary blooms period, and winter minima were reached by November

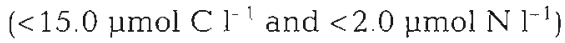

\section{Primary production}

Up to $86 \%$ of the integrated annual primary production occurred during the 6 mo of the productive period, from early April to early October (Fig. 6). Within that period (spring bloom and secondary blooms periods), several maxima in primary production (Fig. 6, see also Fig. 9) occurred. The maximum carbon production rate (2.34 $\mathrm{g} \mathrm{C} \mathrm{m}^{-2} \mathrm{~d}^{-1}$ ) corresponded to the spring bloom period and was reached on 19 April, $24 \mathrm{~d}$ before the maximum surface chl a concentration (Fig. 5a). During the secondary blooms period 3 peaks of primary production were observed. The first one $\left(1.24 \mathrm{~g} \mathrm{C} \mathrm{m}^{-2} \mathrm{~d}^{-1}\right.$ on 14 June) was reached simultaneously with the corresponding peak of chl a. In late July-early August, a peak of primary production $\left(1.18 \mathrm{~g} \mathrm{C} \mathrm{m}^{-2} \mathrm{~d}^{-1}\right)$ overlapped 2 small peaks of chl a. Finally, the productive period ended with an increase of the primary production restricted to the surface layer $\left(91.2 \mathrm{mg} \mathrm{C} \mathrm{m}^{-3} \mathrm{~d}^{-1}\right.$ at the surface but only $0.35 \mathrm{~g} \mathrm{C} \mathrm{m}^{-2} \mathrm{~d}^{-1}$ in the whole water column) and with low chl a content. It is noteworthy that from April to August 1993, when solar radiation was maximum (Fig. 2b), the major peaks of primary 
production extended deep in the water column (Fig. 6). In contrast, during the spring transition periods (March 1993 and March 1994) as well as at the end of the secondary blooms period (September 1993), primary production was confined to the surface.

Due to the importance of vertical mixing and water renewal in the Bay of Brest, oxygen concentrations did not exhibit important seasonal variations; waters were close to saturation or super-saturated with respect to oxygen over the entire water column during most of the annual cycle (Fig 7). Maximal super-saturation was observed during the fall bloom (up to $138 \%$ on 9 September), while transient under-saturation was only moderate and never went below $95 \%$ (minimum observed on 20 Decemberi

\section{DISCUSSION}

As a common feature in many coastal ecosystems (e.g. Legendre et al. 1986, Peterson 1986, Tsuda et al. 1994, Malej et al. 1995) the onset of tho productive period in the Bay of Brest is driven by physical parameters (Ragueneau et al. 1996). In spring 1993 the beginning of the diatom-dominated spring bloom coincided with the stabilization of the water column $\left(\Delta \sigma_{t}\right.$ between surface and bottom waters: $2.78 \mathrm{~g} \mathrm{~kg}^{-1}$ ) due to freshwater discharges, and increased light availability during stratification enabled the enhancement of primary production. However, light limitation was still liable to occur afterwards with regard to the high dayto-day variability of solar radiation (Fig 2b), as also described in similar ecosystems (e.g. Wafar et al. 1983, Lohrenz et al. 1990, Pennock \& Sharp 1994). In the course of the productive period, the fast tidal exchange between the Bay and the ocean waters (Delmas \& Tréguer 1983, Souchu 1986) coupled with reduced freshwater inputs and increasing phytoplankton uptake during spring and summer led to progressive depletion of the nutrients of the Bay. Exhaustion occurred during this period (Fig. 4), suggesting that nutrients exert a close control on primary production.

The potential limitation of primary production by nutrient availability is first approached with reference to the composition of the biogenic matter. According to Redfield et al. (1963) and to Brzezinski (1985), the standard molar ratio for silicic acid, DIN (dissolved inorganic nitrogen $=$ nitrate + nitrite + ammonium $)$, and phosphate is Si:N:P = 16:16:1. This ratio corresponds to the composition of diatoms, which are the primary contributors of the Bay of Brest phytoplankton production (Del Amo et al. 1997), and it also gives estimates of the relative nutrient requirements by diatoms (e.g. Levasseur \& Therriault 1987, Fisher et al. 1992). In Fig. 8a, b the Si:N $=1, N: P=16$ and Si:P $=16$ lines delimit 6

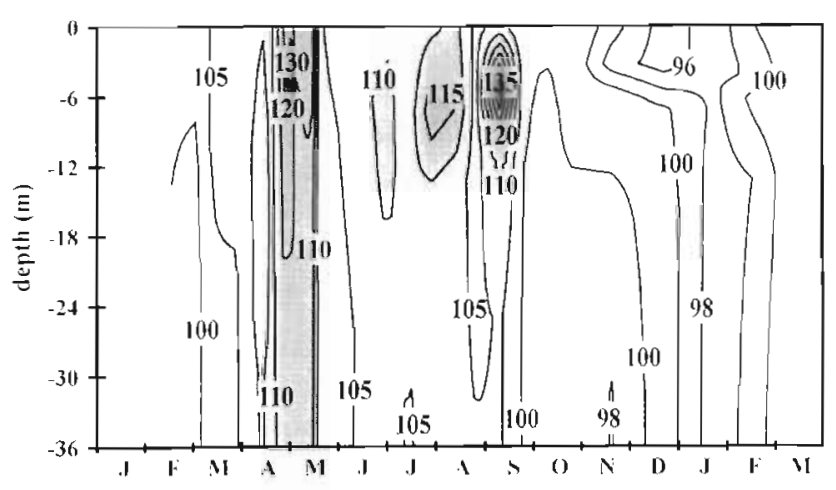

Fig. 7. Seasonal variations of dissolved oxygen saturation values (1n \%) at Stn $\mathrm{R}_{3}$ during 1993-1994

areas, each of them being characterized by the potentially limiting nutrients in order of priority (see Fig. 8 legend). The data points of the 1993-1994 annual cycle are plotted in Fig $8 \mathrm{a}, \mathrm{b}$

During the fall/winter and the spring transition periods (Fig 8a) nutrient concentrations were high (Fig. 4) and therefore nutrient limitation was not likely to occur. The Si:P ratios were close to $16(18.5 \pm 2.5)$, i.e. silicic acid and phosphate were balanced with regard to the potential diatom demand. In contrast, low Si:N $(0.37 \pm 0.04)$ and high $N: P$ ratios $(53.7 \pm 6.3)$ indicated excess DIN originating from river inputs. During this period the 2 major processes that controlled nutrient concentrations in the Bay were the freshwater inputs and the tidal exchange with the adjacent Iroise Sea.

During the productive period (spring bloom and secondary blooms periods), these processes were predominated by phytoplankton uptake and nutrient recycling ( $\mathrm{N}$ and $\mathrm{P}$ regeneration, biogenic silica dissolution) and the nutrient concentrations decreased to very low values (Fig. 4), with residual nutrient ratios clearly different from the standards (Fig. 8b). The locations of the data points in Fig 8 b clearly suggest that $P$ and $\mathrm{Si}$ were the most common potentially limiting major nutrients, but some potentially $\mathrm{N}$-limited events were also evidenced. A comprehensive view of the potential nutrient limitation of phytoplankton production during the productive period, referring to standard Si:N:P ratios, is illustrated in the 2-dimensional (depth and time) diagram (Fig. 8c).

Of course, examination of residual nutrient ratios alone does not give definitive conclusions about the actual limiting nutrient for algal growth, because real limitation depends on the species composition and the specific kinetic curves, as well as on the regeneration rates of each nutrient. An additional approach to determine nutrient limitation is therefore to compare the in situ nutrient concentrations to half-saturation constants for nutrient uptake $\left(K_{\mathrm{m}}\right)$ In situ nutrient concen- 

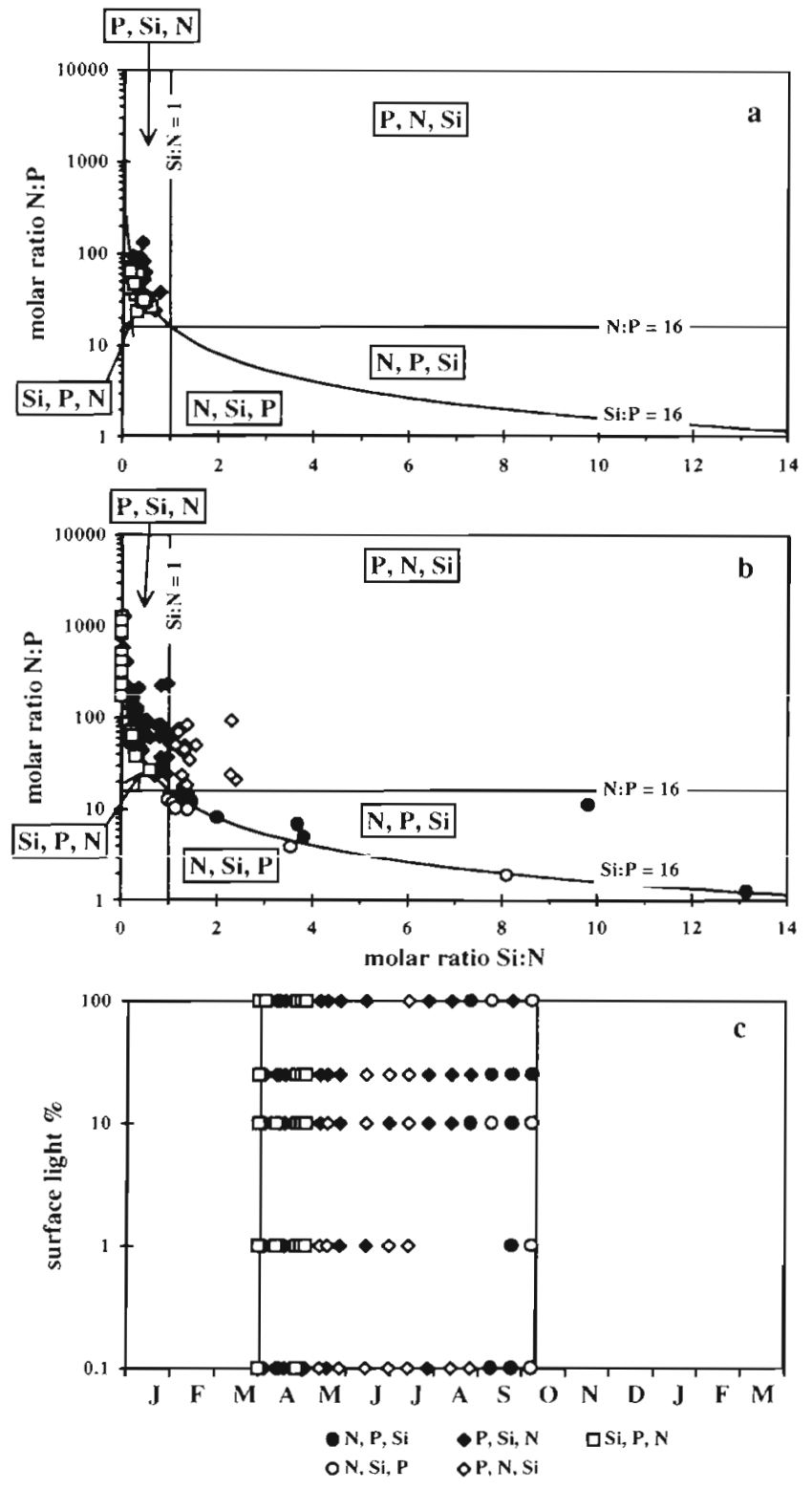

Fig. 8. Synthetic graph of Si:N:P molar ratios in the water column of the Bay of Brest at Stn $R_{3}$ during 1993-1994. In each area del.mited by the Brzezinski (1985) ratio and by the Redfield et al. (1963) ratio (Si:N:P = 16:16:1), the potential limiting nutrients (PLN) are reported in order of priority. (a) Winter period: from 15 February to 1 April 1993 and from 7 October 1993 to 21 March $1994_{i}$ (b) productive period: from 1 April to 7 October 1993 (see text for details): (c) 2-dimensional diagram (over depth and time) showing PLNs in order of priority within the productive period. Circles: N first PLN (- P second PLN; O: Si second PLN); diamonds: P first PLN (

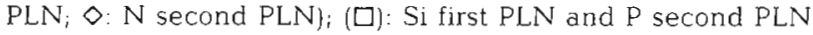

trations below the corresponding $K_{\mathrm{m}}$ corresponded to nutritional conditions that greatly reduced nutrient uptake rates and potentially limited algal growth rates. $K_{\mathrm{m}}$ values reported in the literature for natural popula- tions present a large range of variations (Table 2). For the Bay of Brest, Dauchez et al. (1991) established uptake limitation when nitrate was below $1.6 \mu \mathrm{M}$, which is in agreement with mean $K_{\mathrm{m}}$ values for DIN uptake of 2.0 and $1.0 \mu \mathrm{M}$ respectively proposed by Fisher et al (1988) and Dortch \& Whitledge (1992). The authors of both studies considered mean $K_{\mathrm{m}}$ values of 0.2 and $2.0 \mu \mathrm{M}$ for phosphate and silicic acid uptake, respectively. Indeed, Egge \& Aksnes (1992) reported that diatom dominance occurred when silicic acid concentrations exceeded a threshold of $2.0 \mu \mathrm{M}$. Natural diatom assemblages collected in the Bay of Brest during 1994 yielded $K_{\mathrm{m}}$ values for silicic acid uptake ranging from $1.6 \mu \mathrm{M}$ for summer diatoms to $3.3 \mu \mathrm{M}$ for spring diatoms (Del Amo 1996). Therefore, for the conditions prevailing in the Bay of Brest we herein considered that concentrations $\leq 0.2,2.0$ and $2.0 \mu \mathrm{M}$, for phosphate. silicic acid and DIN, respectively, were limiting for nutrient uptake by phytoplankton during our study period. If we compare the in situ nutrient concentrations to these reference values, it is clear that $\mathrm{Si}, \mathrm{N}$ or $\mathrm{P}$ can be in turn limiting during the productive period (Table 3).

Fig. 9 gives a synthetic view of the most probable chemical limiting factor(s) of phytoplankton growth in the Bay of Brest for each period, taking into account the 2 different approaches considered (potential limitation in reference to standard composition ratios, and comparison between the residual nutrient concentrations and $K_{\mathrm{n}}$ ). The first diatom spring bloom (April to early May) is obviously Si limited (Fig. 9). From 27 April to 3 May 1993 this limitation was especially severe when silicic acid concentrations dropped to $<0.05 \mu \mathrm{M}$, far below the $3.3 \mu \mathrm{M} K_{\mathrm{m}}$ value for spring diatom populations (Del Amo 1996). Such a severe limitation of silicic acid uptake rates provides indirect evidence for Si limitation of diatom growth rates. The silicic acid exhaustion period was indeed followed by the decline of the first primary production peak (diatom dominance $>97 \%$; Del Amo et al, 1997) as in spring 1992 (Ragueneau et al. 1994).

During the first half of the secondary blooms period (until mid-July), most of the silicic acid concentrations stayed below or close to $2 \mu \mathrm{M}$ throughout the water column (Fig. 4). Compared with the $K_{\mathrm{m}}$ value of $1.6 \mu \mathrm{M}$ measured by Del Amo (1996) for summer diatoms, it is clear that, although those concentrations were still sufficient to sustain diatom production, the latter was probably not occurring at its maximal rate. During the same period and even later, phosphate concentrations remained $\leq K_{\mathrm{m}}(0.2 \mu \mathrm{M})$ until early September, and with regard to residual nutrient ratios (Fig $8 \mathrm{c}$ ), P appeared as the primarily limiting nutrient until mid-August. However, despite these permanently low phosphate concentrations (<0.1 $\mu \mathrm{M}$ from 27 April to 12 August), 
Table 2. Ranges of half-saturation constants $\left(K_{\mathrm{m}}\right)$ for nutrient uptake, and optimal algal composıtion or uptake ratios reported in the literature. DIN: dissolved inorganic nitrogen

\begin{tabular}{|lccll|}
\hline & Silicic acid & Phosphate & DiN & Source \\
\hline$K_{\mathrm{tI}}(\mu \mathrm{M})$ & $1-5$ & $0.1-0.5$ & $1-2$ & Fisher et al. (1988) \\
& $0.03-3.37$ & $0.0001-2$ & $0.01-10.3$ & Dortch \& Whitledge (1992) \\
Composition ratios & & $\mathrm{N}: \mathrm{P}=16 ; \mathrm{Si}: \mathrm{P}=16 ;$ Si:N=1 & Redfleld et al. (1963), Brzezinski (1985) \\
& & $\mathrm{N}: \mathrm{P}=7-87 ; \mathrm{Si}: \mathrm{P}=1-96$ & Hecky \& Kilham (1988) \\
& $\mathrm{N}: \mathrm{P}=10-30 ; \mathrm{Si}: \mathrm{P}>3 ; \mathrm{Si}: \mathrm{N}=1$ & & Dortch \& Whitledge (1992) \\
\hline
\end{tabular}

Table 3. Number of data points which suggest nutrient lımitation (total data points in parentheses) according to mean values of $K_{\mathrm{m}}$ (see text for details) during each period

\begin{tabular}{|c|c|c|c|c|}
\hline & Fall/winter & Spring transition & Spring bloom & Secondary blooms \\
\hline $\mathrm{DIN} \leq 2 \mu \mathrm{M}$ & $0(25)$ & $0(27)$ & $4(49)$ & $18(41)$ \\
\hline Silicic acid $\leq 2 \mu \mathrm{M}$ & $0(25)$ & $1(27)$ & $19(49)$ & $11(41)$ \\
\hline Phosphate $\leq 0.2 \mu \mathrm{M}$ & $0(25)$ & $0(27)$ & $45(49)$ & $35(40)$ \\
\hline
\end{tabular}

phytoplankton production did occur during the productive period (Fig. 6). Such a feature has already been described for other coastal systems (e.g. Wafar et al. 1983, Cadee \& Hegeman 1993). Among the 3 major nutrients ( $N, P$ and $\mathrm{Si}$ ), phosphate is probably the more difficult nutrient to assess for primary production limitalion due to its fast biological (Admiraal \& Werner 1983) and geochemical (Lean et al. 1983, Conley et al. 1988) turnover. Furthermore, due to the high reactivity of phosphorus with the suspended matter, processes of adsorption/desorption of phosphate from the particulate matter are liable to control concentrations of dissolved phosphorus in the water column (e.g. Carrit \& Goodgal 1954). A specific study of interactions between the suspended matter and the water column in the Bay of Brest (Delmas 1981) has shown that a single measurement of phosphate concentration in the water column does not allow the correct assessment of actual phosphate availability for phytoplankton growth. Furthermore, optimum composition ratios for phosphate, in comparison with those for the other major nutrients, vary over a large range among phytoplankton species (Table 2) The ranges of these ratios are greater than those of Redfield et al. (1963) and Brzezinski (1985). During the whole productive period, Si:P ratios were seldom $>96$ and high $\mathrm{N}: \mathrm{P}$ values $(\geq 87)$ were found from mid-April to mid-June. Therefore, it seems difficult to discard $\mathrm{P}$ as a limiting nutrient during this period, and both $\mathrm{P}$ and Si limitation could be inferred for the Bay of Brest.

Interestingly, within this secondary blooms period (from May to July), the P, Si limitation order of priority is gradually replaced by a P, N limitation order of priority, and this occurred from the bottom to the surface layers (Fig 8c). This suggests silicic acid regeneration from biogenic silica dissolution at the sediment-water interface, progressively influencing the upper layers during summer (Ragueneau et al. 1994). At that time, when nutrient inputs by riverine discharge are at their lowest (Fig. 2a), silicic acid regeneration should be the main process allowing diatoms to keep growing, the diatoms thus remaining the dominant phytoplankton group throughout the productive period (Del Amo et al. 1997).

Referring to nutrient ratios, $N$ appears to be limiting during the last stage of the secondary blooms period, from late August to early October (Fig 8). Referring to half-saturation constants for DIN uptake (Table 2), very low DIN concentrations likely limited phytoplankton uptake in early July (from 0.8 to $2.0 \mu \mathrm{M}$ in the

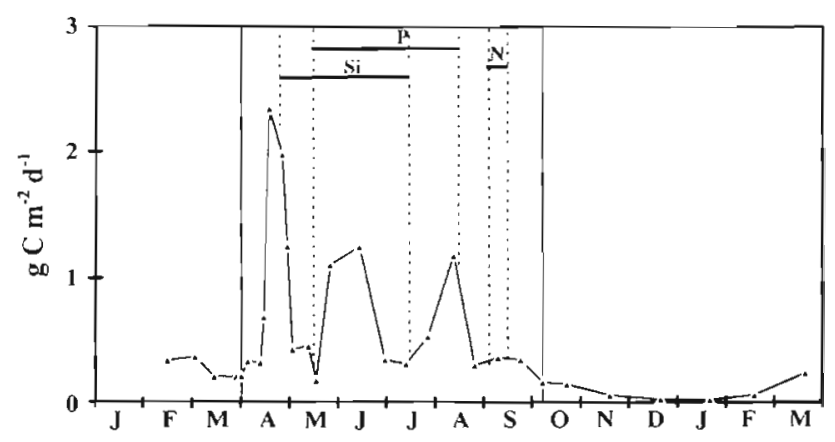

Fig. 9. Seasonal variation of depth-integrated primary production rates at $S t n R_{3}$ durng 1993-1994 and periods of nutrient limitation: Si, silicic acid limitation; P, phosphate limitation; $N$, dissolved nitrogen limitation (see text). Solid vertical lines delineate the productive period 
Table 4. Nutrients inferred for primary production lımitation in some coastal ecosystems and corresponding $\mathrm{SI}_{\mathrm{I}} \mathrm{A}$ ratios in fresh waters from the respective main rivers. 'Pnstine' conditions: natural conditions in the world's major unpolluted nvers. nd: not determined

\begin{tabular}{|c|c|c|c|}
\hline \multirow[t]{2}{*}{ River (coastal ecosystem) } & \multirow{2}{*}{$\begin{array}{l}\text { Riverine } \\
\text { Si:N ratio }\end{array}$} & \multicolumn{2}{|c|}{ Limiting nutrient } \\
\hline & & Spring & Summer \\
\hline 'Pristine' conditions & $17.4^{3}$ & - & - \\
\hline Sacramento-San Joaquin (San Francisco Bay) & $1.4^{2}$ & Si or $N^{2}$ & Not limited ${ }^{4}$ \\
\hline Mississippi (Gulf of Mexico) & $0.9^{3}$ & Si and $P^{7}$ & $N^{7}$ \\
\hline Po (Northern Adriatıc Sea) & $0.7^{3}$ & nd & $p^{12}$ \\
\hline Susquehanna (Chesapeake Bay) & $0.7^{4}$ & $\mathrm{Si}^{8}$ & $\mathrm{~N}^{13}$ \\
\hline Morlaix River (English Channel) & $0.5^{3}$ & $\mathrm{Si}^{9}$ & $\mathrm{~N}^{9}$ \\
\hline Aulne/Elorn (Bay of Brest) & $0.2^{6}$ & $\mathrm{Si}^{10}$ & Si and $P$, then $\mathrm{N}^{10}$ \\
\hline
\end{tabular}

water column), and especially in early September (DIN ranged from 0.2 to $0.7 \mu \mathrm{M}$ ). During this last period nitrate was below the analytical detection limit $(<0.05 \mu \mathrm{M})$ throughout most of the water column (Fig. 4). Consideration of $\mathrm{N}$ limitation could be biased by not taking into account of dissolved organic nitrogen, e.g. urea. Urea concentrations in surface samples were low in July and September 10.4 and $0.5 \mu \mathrm{M}$, respectively; Daniel 1995), and remained $0.6 \mu \mathrm{M}$ until early October (Daniel 1995), i.e. total dissolved nitrogen concentrations were still $<2.0 \mu \mathrm{M}$ during this period. Taking urea into account in Si:N:P ratio calculations for the surface water leads to the conclusion that potential $N$ limitation is likely to occur only by early September. Thus, both approaches support the idea that $\mathrm{N}$ limitation seemed to occur only during the last stage of the productive period (Fig. 9).

Therefore, during the 1993-1994 annual cycle, the diatom-dominated phytoplankton in the Bay of Brest seemed to have been strongly Si limited in the earlier stage of the spring bloom, followed by a potential Si and $\mathrm{P}$ limitation period; late summer growth of phytoplankton populations being $N$ limited. Fifteen years ago (1981-1982) the first nutrient depleted in the Bay during the summer period was nitrate and not silicic acid (Quéguiner 1982, Quéguiner \& Tréguer 1984). Le Pape et al. (1996) reported that summer DIN depleted periods are now less frequent and of shorter duration than 15 yr ago.

Following Officer \& Ryther (1980), Smayda (1990), and Conley \& Malone (1992), this study supports the idea that Si limitation of siliceous-phytoplanktondominated spring blooms represents the response of the Bay of Brest ecosystem to high-nitrate-loaded freshwater inputs. In the 1990s, winter nitrate freshwater concentrations have increased to $>700 \mu \mathrm{M}$ and the Si:N molar ratio in the Bay of Brest tributaries has dropped to 0.2 (Table 4 ), i.e. far below the pristine conditions given by Meybeck (1982). Such a Si:N ratio is among the lowest measured in freshwaters (Table 4); for instance, it is 7 times lower than that for the Sacramento and San Joaquin Rivers (San Francisco Bay; Cloern 1996). Table 4 shows that $\mathrm{Si}$ is the limiting factor for the spring diatom blooms in various manne ecosystems, at least when Si:N ratios in freshwater inputs drop below 1. But coastal ecosystems that are less perturbed by nitrate than the Bay of Brest did not show Si limitation for summer blooms (Table 4). For instance the Gulf of Mexico which receives Mississippi River inputs ( $\mathrm{Si}: \mathrm{N}=0.9$ ) supports summer phytoplankton blooms that are $\mathrm{N}$ limited (Nelson \& Dortch 1996). Comparable situations have been described for the Northern Adriatic Sea (Po River; Revelante \& Gilmartin 1976), the Chesapeake Bay (Susquehanna River; Fisher et al. 1992, D'Elia et al 1992) and the western English Channel (Morlaix River; Wafar et al. 1983). In the Bay of Brest, the dominance of phytoplankton by diatoms during spring and summer in spite of the severe Si limitation is explained by an original 'silicate pump' of well-mixed ecosystems (Del Amo et al. 1997)

Acknowledgements. This research was supported by a Contrat de Baie grant awarded by the Communaute Urbaine de Brest. We thank Hervé Breton, Philippe Cann, Anne Daniel, Christine Hatté and Annick Masson for help with sampling at sea and technical assistance at the laboratory, as well as 4 anonymous referees for their helpful comments. Thanks are also due to the captains, officers and crew members of the Marine Nationale ships for their technical assistance at sea. This work is UMR CNRS 6539 contribution 97005

\section{LITERATURE CITED}

Admiraal W, Werner D (1983) Utilization of limiting concentrations of ortho-phosphate and production of extracellular organic phosphates in cultures of manne diatoms. J Plankton Res 5:495-513

Alpine AE. Cloern JE (1988) Trophic Interactions and direct 
physical effects control phytoplankton biomass and production in an estuary. Limnol Oceanogr 37:946-955

Billen G, Lancelot C. Meybeck M (1991) N, P, Si retention along the aquatic continuum from land to ocean. In: Mantoura RFC, Martin JM, Wollast R (eds) Ocean margin processes in global change. J Wiley \& Sons, New York, p $19-44$

Bodeanu N (1993) Microalgal blooms in the Romanian area of the Black Sea and contemporary eutrophication condltions. In: Smayda TJ, Shumizu Y (eds) Toxic phytoplankton blooms in the sea. Elsevier Science Publishers BV. Amsterdam, p 203-209

Brzezinski MA (1985) The Si:C:N ratio of marine diatoms: interspecific variability and the effect of some environmental variables. J Phycol 21:347-357

Cadee GC, Hegeman J (1993) Persisting high levels of primary production at declining phosphate concentrations in the Dutch coastal area. Neth J Sea Res 31:147-152

Carnt DE, Goodgal S (1954) Sorption reactions and some ecological implications. Deep Sea Res 1:224-228

Cloern JE (1991) Annual variations in river flow and primary production in the South San Francisco Bay estuary. In: Elliot M, Ducrotoy JP (eds) Estuaries and coasts: spatial and temporal intercomparisons. Olsen and Olsen, Fredensborg. p 91-96

Cloern JE (1996) Phytoplankton bloom dynamics in coastal ecosystems: a review with some general lessons from sustained investigation of San Francisco Bay, California. Rev Geophys 34:127-168

Conley DJ, Malone TC (1992) Annual cycle of dissolved silicate in Chesapeake Bay: implications for the production and fate of phytoplankton biomass. Mar Ecol Prog Ser 81 $121-128$

Conley DJ, Quigley MA, Schelske CL (1988) Silica and phosphorus flux from sediments: importance of internal recycling in Lake Michigan. Can J Fish Aquat Sci 45 $1030-1035$

Conley DJ, Schelske CL, Stoermer EF (1993) Modification of the biogeochemical cycle of silica with eutrophication. Mar Ecol Prog Ser 101:179-192

Daniel A (1995) Le cycle de l'azote en écosystème côtier développement d'un analyseur pour la mesure in situ des nitrates et des nitrites; variations saisonnières de la production azotée phytoplanctonique. PhD dissertation, Université de Bretagne Occidentale, Brest

Dauchez S, Quéguiner B, Tréguer P, Zeyons C (1991) A conparative study of nitrogen uptake by phytoplankton in a coastal eutrophic ecosystem (Bay of Brest. France). Oceanol Acta 14:87-95

Del Amo Y (1996) Dynamique et structure des communautés phytoplanctoniques en écosystème côtier perturbé; cinétiques de l'incorporation de silicium par les diatomées. PhD dissertation, Université de Bretagne Occidentale, Brest

Del Amo Y, Quéguiner B, Tréguer P, Breton $\mathrm{H}$, Lampert L. (1997) Impacts of high-nitrate freshwater inputs on macrotidal ecosystems. II. Specific role of the silicic acid pump in the year-round dominance of diatoms in the Bay of Brest (France). Mar Ecol Prog Ser 161:225-237

D'Elia CF, Harding LW Jr, Leffler M, Mackiernan GB (1992) The role and control of nutrients in Chesapeake Bay. Wat Sci Technol 26:2635-2644

Delmas R (1981) Etude de l'évolution saisonnière des sels nutritifs dans la rade de Brest en fonction des apports fluviaux et des échanges avec l'Iroise. PhD dissertation, Université de Bretagne Occidentale, Brest.

Delmas R, Tréguer P (1983) Evolution saisonnière des nutri- ments dans un écosystème eutrophe d'Europe Occidentale (la rade de Brest). Interactions marines et terrestres. Oceanol Acta 6:345-355

Dortch Q, Whitledge TE (1992) Does nitrogen or silicon limit phytoplankton production in the Mississippi River plume and nearby regions? Cont Shelf Res 12:1293-1309

Egge JK, Aksnes DL (1992) Silicate as regulating nutrient in phytoplankton competition. Mar Ecol Prog Ser 83:281-289

Fisher TR, Harding LW Jr, Stanley DW, Ward LG (1988) Phytoplankton, nutrients, and turbidity in the Chesapeake, Delaware, and Hudson Estuaries. Estuar Coast Shelf $S_{C 1}$ 27:61-93

Fisher TR, Peele ER, Ammerman JW, Harding LW Jr (1992) Nutrent limitation of phytoplankton in Chesapeake Bay. Mar Ecol Prog Ser 82:51-63

Gordon LI, Jennings JC, Ross A.A, Krest JM (1994) A suggested protocol for continuous flow automated analysis of seawater nutrients in the WOCE hydrographic program and the Joint Global Ocean Fluxes Study. WOCE Operations Manual, WHP Office Report WHPO 91-1-revision, Corvallis

Hecky RE, Kilham P (1988) Nutrient limitation of phytoplankton in freshwater and marine environments: a review of recent evidence on the effects of enrichment. Limnol Oceanogr 33:796-822

Howarth RW, Billen G, Swaney D, Townsend A, Jaworski N, Lajtha $K$, Downing JA, Elmgren R, Caraco N, Jordan T, Berendse F, Freney J, Kudeyarov V, Murdoch P, Zhu ZI. (1996) Regional nitrogen budgets and riverine $N \& P$ fluxes for the drainages to the North Atlantic Ocean: natural and human influences. Biogeochemistry 35:75-139

Jacq E, Quéguiner B, Prieur D, Tríguer P (1985) Modification de l'aspect des peuplements bactériens en relation avec un bloom phytoplanctonique en rade de Brest. Oceanis 11: $213-222$

Justic D, Rabalais NN, Turner RE (1995) Stoichiometric nutrient balance and origin of coastal eutrophication. Mar Pollut Bull 30:41-46

Koroleff $F$ (1969) Direct determination of ammonium in natural waters as indophenol blue. Int Counc Explor Sea, Comm Meet 9:19-22

Lean DRS, Abbott AP, Charlton MN, Rao SS (1983) Seasonal phosphate demand for Lake Erie plankton. J Gt Lakes Res 9:83-91

Legendre L, Demers S, Lefaivre D (1986) Biological production at marine ergoclines. In: Nihoul JCJ (ed) Marine interfaces ecohydrodynamics. Elsevier, Amsterdam, p 1-29

Le Pape O, Del Amo Y, Ménesguen A, Aminot A, Quéguiner B. Treguer P (1996) Resistance of a coastal ecosystem to increasing eutrophic conditions: the Bay of Brest (France), a semi-enclosed zone of Western Europe. Cont Shelf Res 16:1885-1907

Levasseur ME, Therriault JC (1987) Phytoplankton biomass and nutrient dynamics in a tidally induced upwelling: the role of the $\mathrm{NO}_{3} \mathrm{SiO}_{4}$ ratio. Mar Ecol Prog Ser 39:87-97

Lohrenz SE, Dagg MJ, Whitledge TE (1990) Enhanced primary production at the plume/oceanic interface of the Mississippi River. Cont Shelf Res 10.639-664

Malej A, Mozetič P, Malačič V, Terzıč S, Ahel M (1995) Phytoplankton responses to freshwater inputs in a small semienclosed gulf (Gulf of Trieste, Adriatic Sea). Mar Ecol Prog Ser 120:111-121

Meybeck M (1982) Carbon, nitrogen and phosphorus transport by world rivers. Am J Sci 282:401-450

Meybeck M, Helmer R (1989) The quality of rivers: from pristine stage to global pollution. Paleogeogr Paleoclimatol Paleoecol 75:283-309 
Nelson DM, Dortch Q (1996) Silicic acid depletion and silicon limitation in the plume of the Mississippr River: evidence from kinetic studies in spring and summer. Mar Ecol Prog Ser 136:163-178

Officer CB, Ryther JH (1980) The possible importance of silcon in marine eutrophication. Mar Ecol Prog Ser 3:83-91.

Pennock JR, Sharp JH (1994) Temporal alternation between light-and nutrient-limitation of phytoplankton production in a coastal plain estuary. Mar Ecol Prog Ser 111:275-288

Peterson WT (1986) The effects of seasonal variations in stratification on plankton dynamics in Long Island Sound. In: Bowman J, Yentsch M, Peterson WT (eds) Tidal mixing and plankton dynamics. Springer-Verlag, Berlin, p 297-320

Quéguiner B (1982) Variatıons qualitatives et quantitatives du phytoplancton dans un écosystème eutrophe fortement soumis aux effets des marées: la rade de Brest. PhD dissertation, Université de Bretagne Occidentale, Brest

Quéguiner B, Tréguer P (1984) Studies on the phytoplankton in the Bay of Brest (Western Europe). Seasonal variation in composition biomass and production in relation to hydrological and chemical features (1981-1982). Bot Mar 27:449-459

Ragueneau $O$, De Blas Varela F. Tréguter P. Quéguiner B. Del Amo $Y$ (1994) Phytoplankton dynamics in relation to the biogeochemical cycle of silicon in a coastal ecosystem of western Europe. Mar Ecol Prog Ser 106:157-172

Ragueneau O, Quéguiner B. Tréguer P (1996) Contrast in bioIngiral resnonses to tidally-induced vertical mixing for two macrotidal ecosystems of western Europe. Estuar Coast Shelf Sci 42:645-665

Redfield AC, Ketchum BH, Richards FA (1963) The influence of organisms on composition of seawater. In: Hill MN (ed) The sea, Vol II. J Wiley, New York, p 26-77

Revelante N, Gilmartin M (1976) The effect of Po river discharge on phytoplankton dynamics in the northern Adriatic Sea. Mar Biol 34:259-271

Editorial responsibility: Otto Kinne (Editor).

Oldendorf/Luhe, Germany
SHOM (1968) Courants de marée dans la Manche et sur les cotes francaises de l'Atlantique. Service Hydrographique et Océanographique de la Marino, Brest

Smayda TJ (1990) Novel and nuisance phytoplankton blooms in the sea: evidence for a global epidemic. In: Granélı E (ed) Toxic marine phytoplankton. Elsevıer Science Publushing Co, New York, p 29-40

Souchu P (1986) Contribution à l'étude du cycle de l'azote en icosystème macrotıdal. PhD dissertation, Université de Bretagne Occidentale, Brest

Strickland JDH, Parsons TR (1972) A practical handbook of scawater analysis. Bull Fish Res Bd Can 167

Tréguer P, Le Corre P (1975) Manuel d'analyse des sels nutritifs dans l'eau de mer. Utilisation de l'Auto-Analyseur II 'Irchnicon, 2nd edn. Laboratoire d'Océanographie Chimique, Université de Bretagne Occidentale, Brest

Tréguer $P$, Nelson DM, van Bennekom AJ, DeMaster DJ, Leynaert A, Quéguiner B (1995) The silica balance in the world ocean: a re-estimate. Science 268:375-379

Tsuda A, Sugisaki H, Takahashi K, Furuya K (1994) Succession of pelagic organisms in the sizc-range $0.5-200 \mu \mathrm{m}$ during a diatom bloom in Otsuchi Bay, Japan. Estuar Codst Shell Sci 39:173-184

Turner RE, Rabalais NN (1994) Coastal eutrophication near the Mississippi River delta. Nature 368:61.9-621

Wafar MVM (1981) Nutrients, primary production and dissolved and particulate organic matter in well-mixed temperate coastal waters (Bay of Morlaix-western English Channel). PhD dissertation, Université de Paris

Wafar MVM, Le Corre P. Birrien JL (1983) Nutrients and primary production in permanently well-mixed temperate coastal waters. Estuar Coast Shelf Sci 17:431-446

Yentsch CS, Menzel DW (1963) A method for the determination of phytoplankton chlorophyll and pheophytin by fluorescence. Deep Sea Res 10:221-231

Submitted: April 1, 1996; Accepted: July 10, 1997

Proofs received from author(s): December 15, 1997 